\title{
FEEDING ECOLOGY OF THE MANED WOLF, CHRYSOCYON BRACHYURUS (ILLIGER, 1815) (MAMMALIA: CANIDAE), IN THE ECO- LOGICAL STATION OF ITIRAPINA, SÃO PAULO STATE, BRAZIL.
}

\author{
Adriana de Arruda Bueno, Sonia Cristina da Silva Belentani \& José Carlos Motta-Junior \\ Biota Neotropica v2 (n2) - http://www.biotaneotropica.org.br/v2n2/pt/abstract?article+BN01802022002 \\ Date Received 07/07/2002 \\ Revised 08/26/2002 \\ Accepted 09/23/2002
}

\begin{abstract}
Laboratório de Ecologia Trófica, Departamento de Ecologia, Instituto de Biociências da Universidade de São Paulo, 05508-900, São Paulo, SP, Brazil
\end{abstract}

All correspondence to Adriana A. Bueno, e-mail: abueno@ib.usp.br

\begin{abstract}
The feeding ecology of the maned wolf (Chrysocyon brachyurus) was studied from 1998 to 2002 in the Ecological Station of Itirapina, São Paulo State, southeastern Brazil, including estimates of prey number and biomass consumption. A total of 325 faecal samples was collected in the area. The species is omnivorous, with a broad diet including 68 species or morphospecies of fruits and animals. Armadillos (Dasypodidae), wolf's fruit (Solanum lycocarpum) and small mammals (mostly Clyomys bishopi) were the bulk of the diet, comprising $72.8 \%$ of the total estimated biomass consumed $(185,323.4 \mathrm{~g})$. In terms of frequency of occurrence, on the other hand, only small mammals and other miscellaneous fruits yielded $43.4 \%$ of the total occurrences $(\mathrm{N}=1,054)$. Animal prey ranging from 0.01 and $0.1 \mathrm{Kg}$ were the most captured category, resulting in $44.2 \%$ of 507 captured animals. The maned wolf seems to be seasonally opportunistic, at least for fruits and insects, as indicated by the variation of the consumption of these items along the year. The higher consumption of fruits and animals characteristic of savannah can be an important factor to consider in future management plans for the species.
\end{abstract}

Key words: Chrysocyon brachyurus, maned wolf, savannah, grassland, feeding ecology, diet, Brazil.

\begin{abstract}
Resumo - A dieta do lobo-guará (Chrysocyon brachyurus) foi estudada entre 1998 e 2002 na Estação Ecológica de Itirapina, Estado de São Paulo, incluindo estimativas de número de presas e biomassa ingerida. Um total de 325 amostras fecais foi coletado na área de estudo. A espécie pode ser considerada onívora, com uma dieta variada incluindo 68 espécies ou morfo-espécies de frutos e animais. Os tatus (Dasypodidae), fruta-de-lobo (Solanum lycocarpum) e pequenos mamíferos (principalmente Clyomys bishopi) constituíram a base da dieta, com 72,8\% do total de biomassa consumida $(185.323,4 \mathrm{~g})$. Por outro lado, em termos de frequiência de ocorrência, apenas os pequenos mamíferos e outros frutos compreenderam $43,4 \%$ do total de ocorrências $(\mathrm{N}=1.054)$. Presas animais entre $0,01 \mathrm{e} 0,1 \mathrm{Kg}$ foram as mais consumidas, representando 44,2 \% do total de 507 indivíduos capturados. O lobo-guará apresenta oportunismo sazonal pelo menos para frutos e insetos, a julgar pela variação no consumo desses itens nas diferentes estações do ano. $\mathrm{O}$ alto consumo de frutos e animais provenientes do cerrado deve ser levado em conta em planos futuros de manejo da espécie.
\end{abstract}

Palavras-chave: Chrysocyon brachyurus, lobo-guará, cerrado, campo, ecologia alimentar, dieta, Brasil. 


\section{Introduction}

The maned wolf (Fig. 1), Chrysocyon brachyurus (Illiger, 1815), is the largest (20 to $26 \mathrm{Kg}$ ) canid of the South American continent. It inhabits mostly savannah-like and grasslands habitats in central South America, including all Paraguay, north-eastern Argentina, north-western Uruguay, south-eastern Peru, large parts of central-east Bolivia and central-south Brazil (Langguth 1975, Dietz 1985, Mones \& Olazarri 1990, Nowak 1999). The species is included in the IUCN Red List as a "lower risk - near threatened" species (Hilton-Taylor 2000) whereas in the Brazilian official list it is considered threatened (Bernardes et al. 1990).

The maned wolf is a solitary animal, except in the breeding season, being active mainly in the crepuscularnocturnal period. Its home range varies from 21.7 to 115.0 $\mathrm{Km}^{2}$ (Dietz 1984, 1985, Carvalho \& Vasconcellos 1995, Rodrigues et al. 1998). It is omnivorous, consuming similar proportions of fruits, mostly wolf's fruit (Solanum lycocarpum) and small vertebrates (Dietz 1984, Motta-Junior et al. 1996, Aragona \& Setz 2001, Motta-Junior \& Martins 2002, Jácomo 1999). Medel \& Jaksic (1988) and MottaJunior et al. (1996) pointed out that quantitative studies about the diet of the maned wolf are lacking. Only a few studies, dealing with minimum number of individuals, provided estimates of biomass ingested (e.g., Motta-Junior et al. 1996, Motta-Junior 2000).

The objective of the present study was to quantify the maned wolf's diet as expressed by: frequency of occurrence as a percentage of total occurrences (Dietz 1984), the minimum number of consumed individuals (Emmons 1987), and the estimated biomass ingested (Emmons 1987, MottaJunior et al. 1996). We also investigated if there was any seasonality in the consumption of major groups of food items. Additionally, aspects of prey size distribution and the importance of savannah-like habitats as a source of food for the maned wolf were considered.

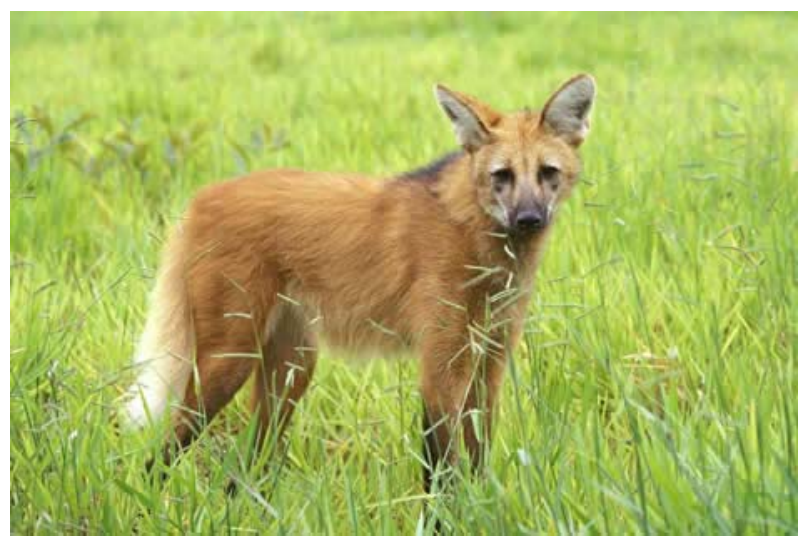

Figure 1. The maned wolf (Chrysocyon brachyurus). (C) J. C. MottaJunior.

\section{Material and Methods}

Fieldwork was conducted from January 1998 to May 2002 in the 2,300 ha Ecological Station of Itirapina (ESI, 22 ${ }^{\circ} 15^{\prime}$ S; 4749' W) and adjacent areas, São Paulo State, Brazil. The climate is rainy/tropical, with two distinct seasons (Köppen's Cwa). The mean annual rainfall is $1,388.7 \mathrm{~mm}$, defining a wet season from October to March (105 to $311 \mathrm{~mm}$ monthly), and a dry season from April to September (18 to $85 \mathrm{~mm}$ ) (RIPASA S/A Meteorological Office, Fazenda Seriema, Brotas, SP). The elevation ranges from $705 \mathrm{~m}$ to $750 \mathrm{~m}$ (SEMA 2000). The ESI protects one of the last remnants of natural cerrado (mostly as savannahs and grasslands) in São Paulo State. The vegetation includes grassland ("campo limpo"), grassland savannah ("campo sujo", see Fig. 2, and "campo cerrado"), and savannah ("cerrado") (see Coutinho 1978). Marshes and gallery forests are also found in the area (Mantovani 1987). Plantations of Pinus sp., Eucalyptus sp. and Citrus sp., besides pastures surround the ESI.

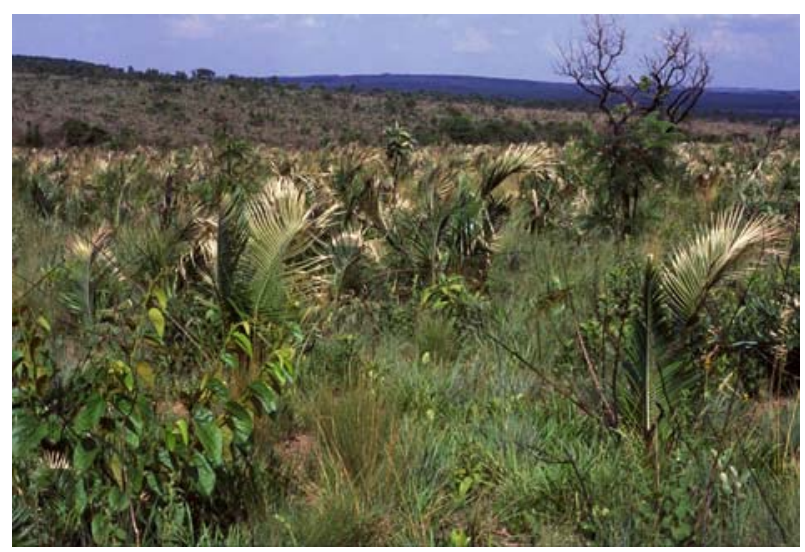

Figure 2. Grassland savannah ("campo sujo") at ESI. (C) J. C. Motta-Junior.

Roads and trails were walked and driven bimonthly from 1998 to July 1999 and once a month for the rest of the study period to search for faecal samples of maned wolf. The samples were then taken to the laboratory and washed in water through a fine (1 mm) mesh screen (Emmons 1987) or in a washing machine (e.g., Springer \& Smith 1981, Uresk $\&$ Sharps 1986). Afterwards, they were oven-dried (at $50^{\circ} \mathrm{C}$ ) during 24-48 hours, stored, and later individually examined.

Remains of teeth, bones, fur, bills, feathers, scales, exoskeletons, and seeds were identified by comparison with a reference collection of the study site available at the Laboratório de Ecologia Trófica (Dep. Ecologia, IB/USP, São Paulo). Specialists from museum and herbaria collections were also consulted for the different groups of prey. The remains of body parts were used to count the minimum number of individual animals consumed (Emmons 1987). The

http://www.biotaneotropica.org.br 
prey biomass consumption was estimated by counting the number of individuals in the faeces and then multiplying this number by the mean body mass of each prey species at the study site (Emmons 1987, Motta-Junior et al. 1996). Body masses of snakes were estimated by the width of the larger ventral scales found in faeces, which was applied in a regression equation (see Appendix). We assumed complete ingestion of prey when teeth, claws and bones of all parts of the skeleton were found in the faeces, including larger prey as armadillos (Motta-Junior et al. 1996). The average number of seeds and mass per fruit species was compared with the number of seeds in faeces to estimate the number of fruits and their biomass ingested by the maned wolf (e.g., Castro et al. 1994). Prey and fruit mass was obtained in the field with spring scales $(1 \mathrm{~g})$. Chi-square goodness-of-fit tests were employed to test for seasonality in the consumption of major food items (see Dietz 1984).

The habitat of each plant and animal consumed was identified by personal observation or literature in order to evaluate the dependence of the maned wolf on savannah species (cf. Motta et al. 1996).

\section{Results and Discussion}

Approximately two to four maned wolves, possibly two couples, were utilising the study area as part of their home ranges, as indicated by sightings and indirect evidence such as faeces and tracks during fieldwork.

A total of 325 faeces were collected (193 and 132 from the dry and wet seasons, respectively), yielding 1,054 occurrences of 68 identified prey and fruit items (see Appendix). We believe our sample is representative of the maned wolf's diet in the study site, since $95 \%$ of all items were already found among the first 200 faeces. No new food item was added after the analysis of the 305 th faeces.

Twenty-four (35.3\%) items were plant material and 44 $(64.7 \%)$ were animal material (see Appendix). By frequency of occurrence, the wolf consumed plant and animal items in similar proportions $(49.3 \%$ and $50.7 \%$, respectively; Table 1). Even though the sample portraits the diet of a few individuals, these results are in the range shown in other studies (Dietz 1984, Motta-Junior et al. 1996, Motta-Junior 2000, Aragona \& Setz 2001), which also described a typically omnivorous diet for this canid. The most consumed items in our study (Table 1 ) were rodents $(22.5 \%)$ and miscellaneous fruits $(20.6 \%)$. In contrast, according to the biomass ingested, the most important items were armadillos (36.2\%) and wolf's fruits (19.6\%) (Figs. 3 and 4, respectively) (Table 1). Although the most abundant armadillo species at ESI were Cabassous unicinctus and Euphractus sexcinctus (Bonato 2002), the maned wolf consumed mainly Dasypus spp. (see Appendix). It is possible that the low incidence of C. unicinctus in the wolf's diet is due to its primarily diurnal habits (Bonato 2002) and its fast-digging ability (Redford

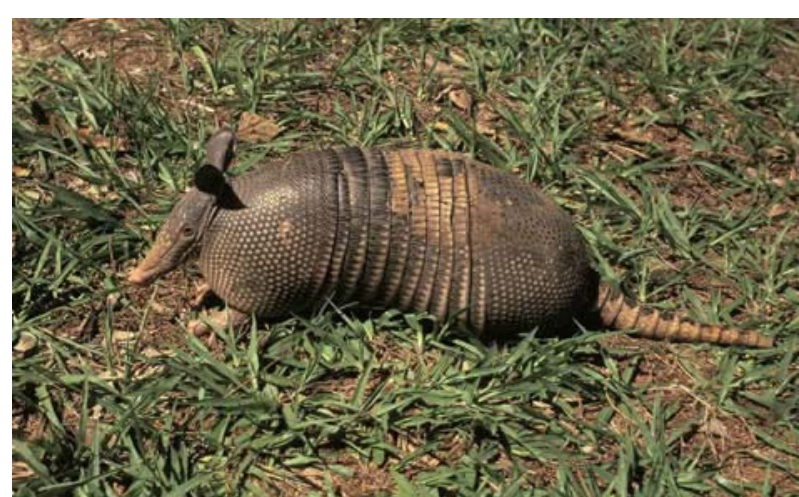

Figure 3. The nine-banded armadillo (Dasypus novemcinctus). C J. C. Motta-Junior.

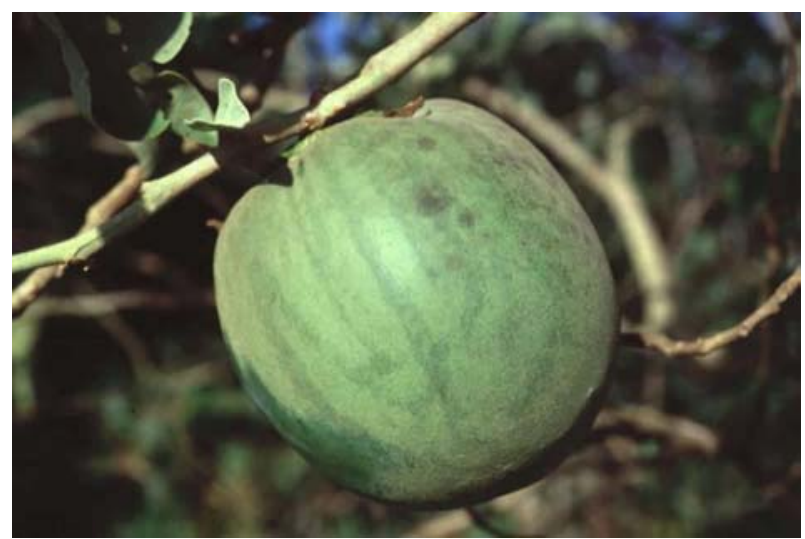

Figure 4. The wolf's fruit (Solanum lycocarpum). (C) J. C. MottaJunior.

1994). The lack or low consumption of the diurnal-nocturnal E. sexcinctus (Bonato 2002) noted at ESI (this study) and reported for other areas (Motta-Junior et al. 1996, MottaJunior 2000, Belentani 2001) may be explained by an escape strategy that includes mainly running and secondarily digging (Redford 1994). On the other hand, Dasypus spp. (Fig. 3 ) is commonly reported in the maned wolf's faeces, even though they were not frequently found at ESI (Bonato 2002), suggesting higher vulnerability to predation or selection by the wolf.

The maned wolf's diet varied seasonally. While wolf's fruit $\left(c^{2}=23.3 ; p<0.001\right)$ and grass leaves $\left(c^{2}=7.8 ; p<0.005\right)$ were consumed mainly during the dry season, other fruits $\left(c^{2}=47.2 ; \mathrm{p}<0.001\right)$ and insects/arthropods $\left(c^{2}=6.9 ; \mathrm{p}<0.01\right)$ were consumed mainly during the wet season (Fig. 5). Although the availability of food resources was not assessed in the study site, other researchers in Brazilian savannahs reported that fruits and insects are more abundant in the wet season (Dietz 1984, Motta-Junior 2000, Belentani 2001). Thus, the maned wolf appeared to feed opportunistically on these groups also in the study area. The maned wolf seemed to switch from the wolf's fruits to other wild fruits, with fruit in general present in the diet along the whole year (Fig. 5). This fact was also reported by Motta-Junior (2000). The high consumption of grass leaves $(12.0 \%$ of total oc- 
currences), mainly during the dry season, may have a beneficial effect in the digestion process (Dietz 1984), though they were not significant in the biomass analysis (Table 1). All other items were consumed in similar proportion in both seasons (Fig. 5).

In spite of its large body size, the maned wolf consumed mainly small vertebrates between 0.01 and $0.1 \mathrm{~kg}$ (44.2\% of a total number of 507 individuals), represented mostly by small mammals, which accounted for the bulk of the animal prey (Fig. 6A). This apparent preference for smaller prey could be a result of its solitary hunting strategy and/or due to the most common prey size found in the study site (J. A. Simonetti, pers. comm.). However, the most consumed rodent was Clyomys bishopi $(277.3 \mathrm{~g})$. This spiny rat (Fig. 7) is reported to be one of the most abundant small mammals in the ESI (Vieira 1997, A. A. Bueno \& S. C. S. Belentani, unpublished data), and this may explain the high consumption. Predation on this species by wolves was lower in areas where it was less abundant (Carvalho 1976, Bueno \& Motta-Junior, submitted). On the other hand, vertebrates, mostly armadillos, weighing between 1.0 and $10.0 \mathrm{~kg}$ yielded $59.0 \%$ from a total of $126,383.4 \mathrm{~g}$ (Fig. 6B). The high biomass proportion of armadillos in the maned wolf's diet has already been found in other studies (Motta-Junior et al. 1996, Belentani 2001, Bueno \& Motta-Junior, submitted).

Savannah destruction due to farming practices seems to be one of the main causes for the decline of maned wolf populations (Dias 1994, Silva 1994). Road mortality may also be another important cause of non-natural death (Rodrigues et al. 1998), although this has not yet been systematically studied.

Considering only identified items, for which it was possible to determinate their habitats, the animal prey and fruits found in the faeces showed that grasslands and savannahs were the major source of food for this canid, regardless of the level of analysis (Table 2). Despite the use of areas with high degree of disturbance around the ESI, our results indicated that the wolves were foraging mainly in the savannah and grassland remnants. These findings

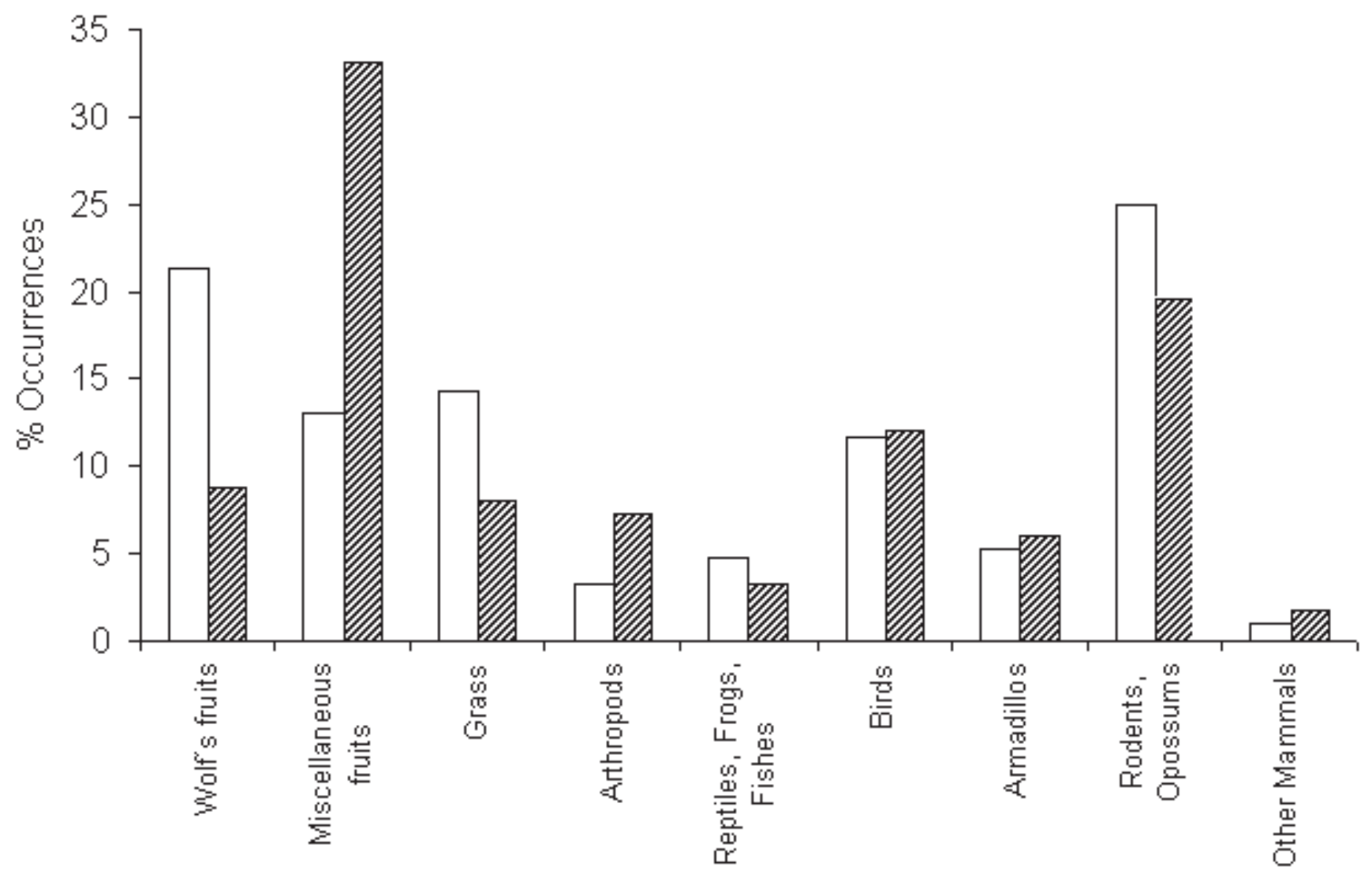

Dry Season wet Season

Figure 5. Seasonality in the consumption of major food item groups in the maned wolf's diet by frequency of occurrence, Ecological Station of Itirapina, southeastern Brazil. Values are percentages from 656 occurrences in the dry season and 398 occurrences in the wet season.

http://www.biotaneotropica.org.br 


\begin{tabular}{|c|c|c|c|}
\hline Fooditems & Occurrenre & Fumber & Biomass \\
\hline Wor's fruit (Solanum lycocopupd) & 16.6 & & 19.6 \\
\hline Miscellane ous fruts & 20.6 & & 12.1 \\
\hline Grains & 0.1 & & tr \\
\hline Grasses and leaves & 12.0 & & 0.1 \\
\hline Subtotal Flants & 49.3 & & 31.8 \\
\hline Insects and other arthropods & 4.8 & 179 & tr \\
\hline Fishes & 0.4 & 08 & 0.5 \\
\hline Froge & 0.3 & 06 & tr \\
\hline Snakes & 3.5 & 5.7 & 1.0 \\
\hline Lizards & 0.2 & 0.4 & tr \\
\hline Birds & 11.9 & 179 & 4.9 \\
\hline Opossums & 0.3 & 0.4 & 0.8 \\
\hline Ammadillos & 5.5 & 8.1 & 36.2 \\
\hline Roderts & 22.5 & 458 & 16.2 \\
\hline Rabbits & 1.0 & 18 & 4.5 \\
\hline Other mammals & 0.3 & 06 & 4.0 \\
\hline Subtotal Animals & 50.7 & 1000 & 68.2 \\
\hline Total (oc currence, number, hiomass) & $\overline{1,054}$ & 507 & $\overline{185,323.4}$ \\
\hline
\end{tabular}

Fote: tr - traces, vabues below $0.05 \%$.

Table 1. Occurrence, number of animal prey and biomass of major groups of food items in the diet of the maned wolf at ESI. Values are percentages. The number of individual fruits consumed was not considered here because of difficulties for comparisons with that of animals. The total value for biomass is in grams. 

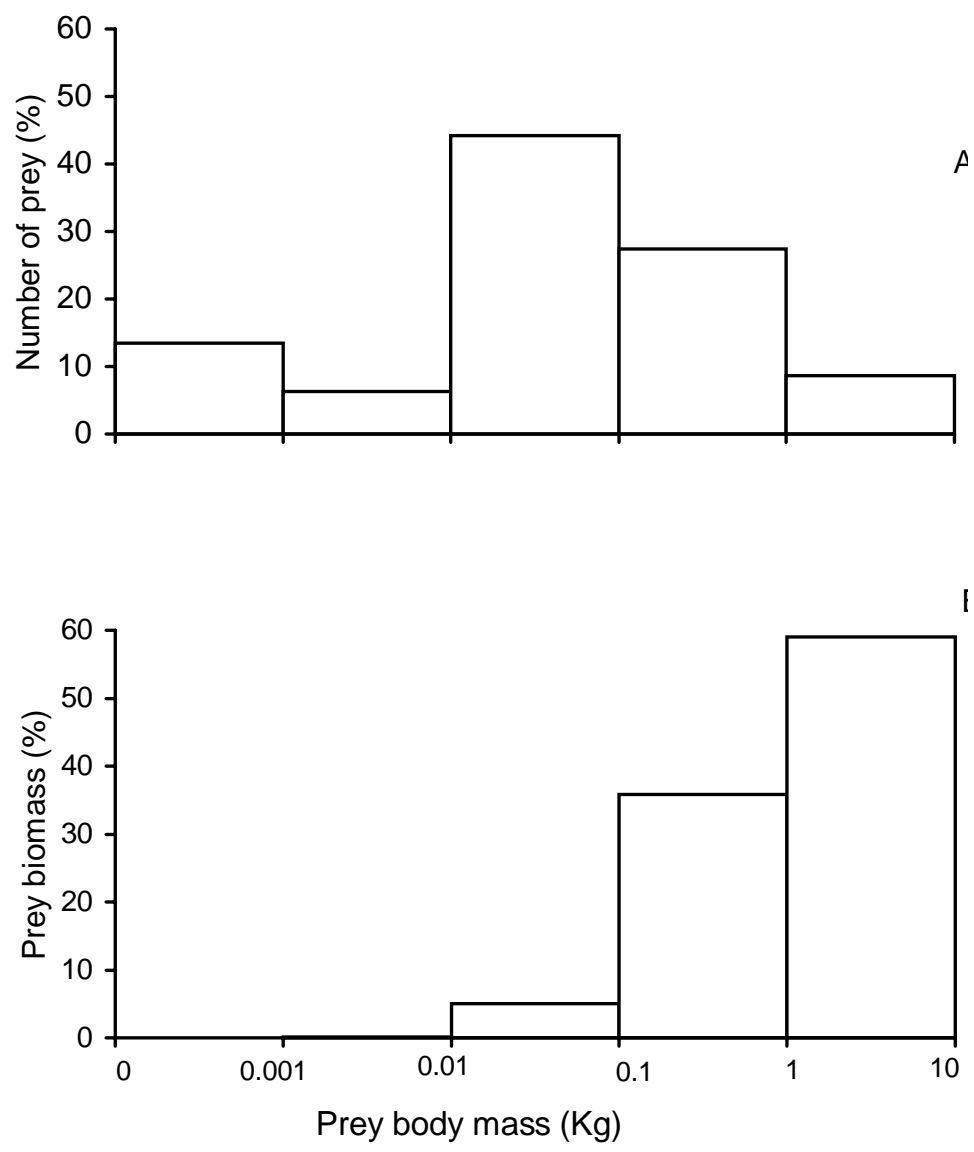

Figure 6. Proportions of number of individuals (A) and biomass (B) of prey represented in faeces, as a function of prey body weight class, in the EIS, southeastern Brazil. Values are percentages from 507 prey individuals and 126,38 Kg of total animal biomass.

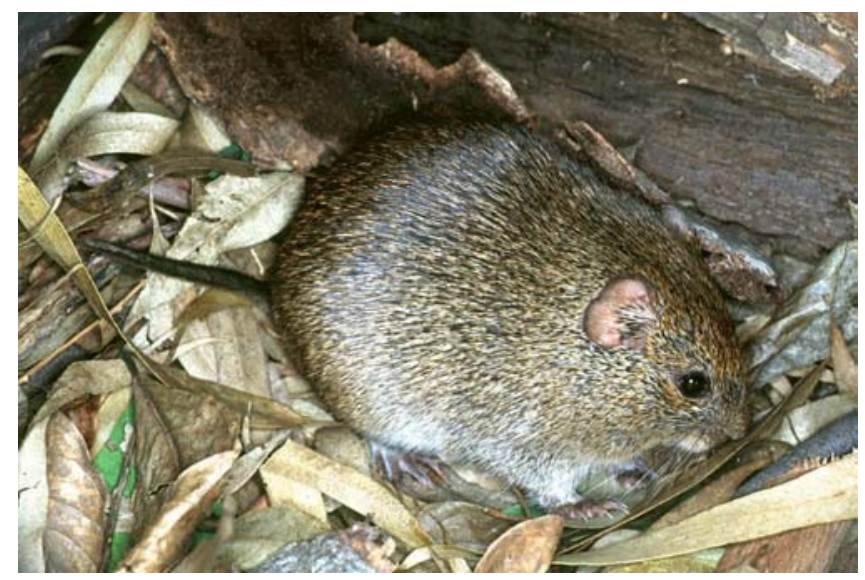

Figure 7. The spiny rat Clyomys bishopi. (C) J. C. Motta-Junior. 


\begin{tabular}{lcccc}
\hline Habitat & $\begin{array}{c}\text { Number } \\
\text { of sp ecies }\end{array}$ & Occurrences & $\begin{array}{c}\text { Numb er of } \\
\text { ind ividuals }\end{array}$ & Biomass \\
\hline Savannah and Grassl and & $24(35.3)$ & $506(48.0)$ & $214(42.2)$ & $80,164.5(43.3)$ \\
Savannah and G allery forest & $9(13.2)$ & $122(11.6)$ & $49(9.7)$ & $76,428.9(41.2)$ \\
Disturbed & $5(7.4)$ & $44(4.2)$ & $13(2.0)$ & $1,456.7(0.8)$ \\
Unknown & $30(44.1)$ & $382(36.2)$ & $230(45.4)$ & $27,273.3(14,7)$ \\
\hline TOTAL & $\mathbf{6 8 ( 1 0 0 . 0 )}$ & $\mathbf{1 0 5 4 ( \mathbf { 1 0 0 . 0 ) }}$ & $\mathbf{5 0 7 ( 1 0 0 . 0 )}$ & $\mathbf{1 8 5 , 3 2 3 . 4 ( 1 0 0 . 0 )}$ \\
\hline
\end{tabular}

Table 2. Distribution of prey and fruits found in faeces of the maned wolf by habitat. Data computed from Appendix. Values in parenthesis are percentages.

are in accordance with those from studies in south-eastern and central Brazil (Motta-Junior et al. 1996, Belentani 2001, Bueno \& Motta-Junior, submitted), emphasising the high value of savannah and grasslands for the survival of the maned wolf.

\section{Acknowledgements}

We thank to Roberto M. Shimizu for reviewing an earlier version of the manuscript. Denise Zanchetta and Instituto Florestal de São Paulo provided facilities at the ESI. Alexandre Tozetti helped with collection of some faeces. Márcio R. C. Martins aided with identification of reptiles and Julio A. Lombardi identified some fruits. Alexandre Percequillo identified some small mammals. FAPESP (Process 00/12339-2) and CAPES provided financial support. This is the publication number 12 of the project "Ecology of the cerrados of Itirapina".

\section{References}

ARAGONA M. \& SETZ, E.Z.F. 2001. Diet of the maned wolf, Chrysocyon brachyurus (Mammalia: Canidae), during wet and dry seasons at Ibitipoca State Park, Brazil. J. Zool. Lond. 254:131-136.

BELENTANI, S.C.S. 2001. Ecologia alimentar do Lobo-guará, Chrysocyon brachyurus (Mammalia: Canidae), no Parque Florestal Salto e Ponte, município de Prata, MG. MSc. Dissertation, Universidade de São Paulo, São Paulo, SP.

BERNARDES, A.T., MACHADO, A.B.M. \& RYLANDS, A.B. 1990. Fauna brasileira ameaçada de extinção. Fundação Biodiversitas/IBAMA, Belo Horizonte.

BONATO, V. 2002. Ecologia e história natural de tatus do cerrado de Itirapina, São Paulo (Xenarthra: Dasypodidae). MSc. Dissertation, Universidade Estadual de Campinas, São Paulo, SP.

BUENO, A.A. \& MOTTA-JUNIOR, J.C. (submitted). Quantitative studies on the diet of the maned wolf,
Chrysocyon brachyurus (Carnivora: Canidae), in Southeast Brazil. Rev. Biol. Trop.

CARVALHO, C.T. 1976. Aspectos faunísticos do cerrado: o lobo-guará (Mammalia, Canidae). Bol. Téc. I. F., S. Paulo 21:1-18.

CARVALHO, C.T. \& VASCONCELLOS, L.E.M. 1995. Disease, food and reproduction of the maned wolf Chrysocyon brachyurus (Illiger) (Carnivora, Canidae) in southeast Brazil. Revta. Bras. Zool. 12(3):627-640.

CASTRO, S.A., SILVA, S.I., MESERVE, P.L., GUTIERREZ, J.R., CONTRERAS, L.C. \& JAKSIC, F.M. 1994. Frugivoría y dispersión de semillas de pimiento (Schinus molle) por el zorro culpeo (Pseudalopex culpaeus) en el Parque Nacional Fray Jorge (IV Región, Chile). Rev. Chil. Hist. Nat. 67:169-176.

COUTINHO, L.M. 1978. O conceito de Cerrado. Rev. Bras. Bot. 1:17-23.

DIAS, B. 1994. Conservação da natureza no cerrado brasileiro. In Cerrado: caracterização, ocupação e perspectivas (M. N. Pinto, Ed.). $2^{\text {nd }}$ edn. Editora Universidade de Brasília, Brasília, p. 607-663.

DIETZ, J.M. 1984. Ecology and social organization of the maned wolf (Chrysocyon brachyurus). Smithsonian Contrib.Zool. 392:1-51.

DIETZ, J.M. 1985. Chrysocyon brachyurus. Mammalian Species 234:1-4.

EISENBERG, J.F. \& REDFORD, K.H. 1999. Mammals of the Neotropics. The central neotropics. v. 3. University of Chicago Press, Chicago.

EMMONS, L.H. 1987. Comparative feeding ecology of felids in a neotropical rainforest. Behav. Ecol. Sociobiol. 20:271-283.

HILTON-TAYLOR, C. (compiler) 2000. 2000 IUCN Red List

http://www.biotaneotropica.org.br 
of Threatened Species. IUCN, Gland, Switzerland and Cambridge, UK.

JÁCOMO, A. T. A. 1999. Nicho alimentar do lobo-guará (Chrysocyon brachyurus Illiger, 1811) no Parque Nacional das Emas - GO. MSc. thesis, Universidade Federal de Goiás, Goiania, Brazil.

LANGGUTH, A. 1975. Ecology and evolution in the South American canids. In The wild canids: their systematics, behavioral ecology and evolution (M.W. Fox, ed.). Van Nostrand Reinhold Co, New York, p.192-206.

MANTOVANI, W. 1987. Análise florística e fitossociológica do estrato herbáceo-subarbustivo do cerrado na reserva biológica de Guaçu e Itirapina. PhD. Thesis, Universidade Estadual de Campinas, Campinas, SP.

MEDEL, R.G. \& JAKSIC, F.M. 1988. Ecología de los cánidos sudamericanos: una revisión. Rev. Chil. Hist. Nat. 61:6779.

MENDONÇA, R.C., FELFILI, J.M., WALTER, B.M.I., SILVA JUNIOR, M.C.S., REZENDE, A.V., FILGUEIRAS, T.S \& NOGUEIRA, P.E. 1998. Flora vascular do cerrado. In Cerrado: ambiente e flora (S.M. Sano, \& S. P. Almeida, eds.). EMBRAPA, Planaltina, p. 289-556.

MONES, A. \& OLAZARRI, J. 1990. Confirmación de la existencia de Chrysocyon brachyurus (Illiger) en el Uruguay (Mammalia: Carnivora: Canidae). Comunicaciones Zoológicas del Museo de Historia Natural de Montevideo 174(7):1-6.

MOTTA JUNIOR, J.C. 2000. Variação temporal e seleção de presas na dieta do lobo-guará, Chrysocyon brachyurus (Mammalia: Canidae), na Estação Ecológica de Jataí, Luiz Antônio, SP. In Estudos integrados em ecossistemas. Estação Ecológica de Jataí (J.E. Santos \& J.S.R. Pires, eds.). v.1. Rima Editora. São Carlos, p.331-346.

MOTTA-JUNIOR, J.C. \& MARTINS, K. 2002. The frugivorous diet of the maned wolf, Chrysocyon brachyurus, in Brazil: ecology and conservation. In Seed Dispersal and Frugivory: Ecology, Evolution and Conservation (D. J. Levey, W. R Silva \& M. Galetti, eds.). CABI Publishing, Wallingford, Oxfordshire, p.291-303.

MOTTA-JUNIOR, J.C., TALAMONI, S.A., LOMBARDI, J.A. \& SIMOKOMAKI, K. 1996. Diet of the maned wolf, Chrysocyon brachyurus, in central Brazil. J. Zool., Lond. 240:277-284.

NOWAK, R.M. 1999. Walker's mammals of the world. v.2. $6^{\text {th }}$ edition. The John Hopkins University Press, Baltimore and London.

REDFORD, K.H. 1994. The Edentates of the Cerrado. Edentata 1(1):4-10.
RODRIGUES, F.H.G., HASS, A., LACERDA, A.C.R. \& GRANDO, R.L.S.C. 1998. Biologia e conservação do lobo-guará na Estação Ecológica de Águas Emendadas, Anais do Seminário "Pesquisa em Unidades de Conservação” 1:28-42.

SÃO PAULO 1994. IF - Série Registros Instituto Florestal, São Paulo. Ed. Especial, no. 12.

SEMA (SECRETARIA DEESTADODO MEIO AMBIENTE) 2000. Atlas das unidades de conservação ambiental do Estado de São Paulo. São Paulo: Secretaria de Estado do Meio Ambiente.

SILVA, J.A.S. 1994. Lobo-guará. In Livro vermelho dos mamíferos brasileiros ameaçados de extinção. (G.A.B. Fonseca, A.B., Rylands, C.R.M. Costa, R.B. Machado, \& Y.L.R. Leite, eds.). Fundação Biodiversitas, Belo Horizonte, p.281-288.

SPRINGER, J.T. \& SMITH, J.S. 1981. Summer food habits of coyotes in Central Wyoming. Great Basin Naturalist 41(4):449-456.

URESK, D. \& SHARPS, J.C. 1986. Denning habitat and diet of the swift fox in Western South Dakota. Great Basin Naturalist 46(2):249-253.

VIEIRA, M.V. 1997. Dynamics of a rodent assemblage in a cerrado of southeast Brazil. Rev. Brasil. Biol. 57(1):99107.

APPENDIX. List of plant and animal items found in the maned wolf's diet at ESI. Numerical data are respectively mean weight $(\mathrm{g})$ of one fruit or individual animal in parentheses; occurrence; number of individual prey for animals; estimated biomass ( $\mathrm{g}$ ) in brackets; and preferred habitat. Abbreviations for habitat: SG - savannah and grassland, FS - gallery forest and savannah/grassland, DT - disturbed, UN - unknown.

\section{Fruits}

Alibertia sp. ${ }^{\mathrm{a}}$ - (6.9); 6; [421.5]; SG

Anacardium cf. humile - (30.0); 1; [30.0]; SG

Andira cf. humilis - (20.0); 1; [20.0]; SG

Annona cf. crassiflora $^{\text {a }}$ - (1,021.0); 1 ; [263.6]; SG

Annona sp. - (136.4); 15; [821.0]; UN

Bromelia anthiacantha - (19.0); 30; [3,081.8]; SG

Campomanesia pubescens $^{\mathrm{a}}$ - (2.0); 62; [666.0]; SG

Citrus sp. ${ }^{\mathrm{a}}-(128.5) ; 25 ;[9,137.5]$; DT

Couepia cf. grandiflora $^{\text {a }}$ - (13.2); $1 ;$ [48.0]; FS

Duguetia furfuracea $^{\text {a }}$ (75.8); 4; [65.5]; SG

Mangifera indica - (200.0); 1; [200.0]; DT

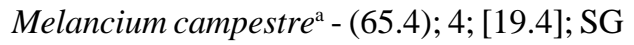

Psidium guajava - (46.3); 11; [817.6]; FS

Psidium cf. cinereum - (4.8); 20; [3,137.8]; SG

Peritassa campestris - (18.3); 10; [1,466.8]; SG 
Pouteria torta ${ }^{\mathrm{a}}$ - (15.0); 5; [854.8]; SG

Pouteria cf. ramiflora ${ }^{\text {a }}$ - (14.0); 2; [136.0]; FS

Solanum lycocarpum - (370.0); 175; [36,356.8]; SG

Solanum sp. - (2.4); 1; [22.5]; DT

Syagrus romanzofiana ${ }^{\mathrm{a}}$ - (5.2); 5; [968.8]; FS

Syagrus cf. petrea - (4.7); 10; [267.6]; SG

Unidentified Palmae - (4.0); 2; [17.0]; UN

\section{Grains}

Phaseolus vulgaris - (0.5); 1; [7.0]; DT

\section{Grasses}

Poaceae and Cyperaceae $^{\mathrm{b}}$ - 126; [113.0]; UN

\section{Insects and Arthropods}

Araneae- (1.0); $1 ; 1 ;[1.0]$; UN

Termitidae - (0.08); $1 ; 5 ;[0.4]$; UN

Blattidae/Parahormetica sp. - (1.8); 7; 6; [10.8]; UN

Acridoidea- (1.5); 2; 2; [3.0]; UN

Tettigoniidae/Copiphorinae- (1.0); 2; 3; [3.0]; UN

Gryllidae- (0.9); $1 ; 1 ;$ [0.9]; UN

Orthoptera unidentified - (1.0); 6; 6; [6.0]; UN

Carabidae Calosoma sp. - (0.7); 1; 1; [0.7]; UN

Scarabaeidae/Dichotomius sp. - (1.0); $1 ; 1 ;[1.0]$; UN

Scarabaeidae/Bothynus sp. - (2.0); 6; 12; [24.0]; UN

Scarabaeidae/Phanaeus sp. - (4.0); 1; 1; [4.0]; UN

Scarabaeidae unidentified - (2.0); $1 ; 1 ;[2.0]$; UN

Coleoptera unidentified - (1.0); 8; 8; [8.0]; UN

Vespidae-(0.02); 5; 36; [0.5]; UN

Unidentified insects - (1.0); 8; 7; [7.0 ]; UN

Fishes

Unidentified Fish - (250.0); 4; 4; [1,000.0]; UN

\section{Frogs}

Unidentified frogs $\mathrm{s}^{\mathrm{c}}$ - (13.8); 3; 3; [41.4]; UN

Lizards

Gymnopthalmidae $^{\mathrm{c}}$ - (2.0); 1; 1; [2.0]; SG

Unidentified small lizard $^{\mathrm{c}}$ - (7.5); $1 ; 1 ;$ [7.5]; UN

\section{Snakes}

Unidentified snakes - $\left({ }^{\mathrm{d}}\right) ; 36 ; 29 ;[1,710.5]$; UN

\section{Birds}

Rynchotus rufescens - (870.0); 1; 1; [870.0]; SG

Tinamidae unidentified - (206.3); 4; 3; [619.0]; SG

Mycropygia schomburgkii-(32.0); 4; 3; [96.0]; SG

Gallus gallus - (400.0); 16; 13; [5200.0]; DT

Volatina jacarina - (10.0); 4; 4; [40.0]; SG

Unidentified Emberizidae - (15.0); 4; 4; [60.0]; UN

Eggs - (10.0); 4; 3; [30.0]; UN

Unidentified small Passerines - (15.0); 23; 18; [270.0]; UN

Unidentified small birds - (30.0); 53; 36; [1,080.0]; UN

Unidentified medium birds - (100.0); 9; 4; [400.0]; UN

Unidentified large birds - (200.0); 3; 2; [400.0]; UN

\section{Mammals}

Cabassous unicinctus - $(2,950.0) ; 3 ; 3 ;[8,850.0]$; SG

Dasypus cf. novemcinctus - (1,787.5); 42; 25; [44,687.5]; FS

Dasypus cf. septemcinctus ${ }^{\mathrm{e}}-(1,045.0) ; 13 ; 13 ;[13,585.0]$;

FS

Didelphis albiventris - (720.9); 3; 2; [1,441.8]; FS

Bolomys lasiurus - (42.4); 6; 19; [805.6]; SG

Calomys tener - (14.3); 32; 62; [114.4]; SG

Oryzomys cf. subflavus - (74.4); 4; 4; [297.6]; SG

Clyomys bishopi-(277.3); 111; 78; [21,629.4]; SG

Oligoryzomys nigripes - (17.2); 7; 11; [189.2]; SG

Cavia aperea - (390.0); 34; 26; [6,340.0]; FS

Unidentified small rodents ${ }^{\mathrm{e}}$ - (20.0); 45; 32; [640.0]; UN

Sylvilagus brasiliensis - (933.8); 11; 9; [8,404.2]; FS

Unidentified medium mammal - (2,500.0); 3; 3; [7,500.0]; UN

Citations: All weights are from field data except where indicated:

$\left({ }^{a}\right)$ Motta-Junior \& Martins (2002); ( $\left.{ }^{b}\right)$ net weight of ingested grass was estimated by previous known net and dry mass of samples from the field; $\left({ }^{c}\right)$ Marcio R. C. Martins, pers. comm.; $\left({ }^{d}\right)$ the larger width of ventral scale from faeces was measured and applied as the independent variable (X) to the regression equation: $\log Y=2.669 \log X-1,540$, where $\mathrm{Y}$ is the dependent variable body mass $\left(\mathrm{R}^{2}=0.999 ; \mathrm{p}<\right.$ $0.0001 ; \mathrm{N}=5$ snakes collected in the area); $\left({ }^{\mathrm{e}}\right)$ Motta-Junior et al. (1996). References consulted for prey and plant habitats were: Mendonça et al. (1998) and Motta-Junior \& Martins (2002) for fruits; Márcio R. C. Martins (pers. comm.) for reptiles; Motta-Junior et al. (1996) for birds; Redford (1994) and Bonato (2002) for armadillos; Eisenberg \& Redford (1999) and Motta-Junior et al. (1996) for other mammals.

\begin{tabular}{|c|}
\hline $\begin{array}{l}\text { Títle: FEEDING ECOLOGY OF THE MANED WOLF, } \\
\text { CHRYSOCYON BRACHYURUS (ILLIGER, 1815) (MAM- } \\
\text { MALIA: CANIDAE), IN THE ECOLOGICAL STATION } \\
\text { OF ITIRAPINA, SÃO PAULO STATE, BRAZIL. }\end{array}$ \\
\hline $\begin{array}{l}\text { Authors: Adriana de Arruda Bueno, Sonia Cristina da } \\
\text { Silva Belentani \& José Carlos Motta-Junior }\end{array}$ \\
\hline $\begin{array}{l}\text { Biota Neotropica, Vol. 2, number 2: } 2003 \\
\text { http://www.biotaneotropica.org.br/v2 n } 2 / \mathrm{pt} / \\
\text { a b s t r a c t ? a r t i c } 1 \text { e + B N } 01802022002 \\
\text { ISSN } 1676-0611 \\
\text { Date Received 07/07/2002 - Revised 08/26/2002- } \\
\text { Accepted 09/23/2002 }\end{array}$ \\
\hline
\end{tabular}

